\title{
Pengaruh jamur tiram putih (pleurotus ostreatus) terhadap kadar glukosa darah, profil lipid dan kadar MDA pada tikus (rattus norvegicus) diabetes melitus
}

\author{
Purbowati $^{1}$, Andrew Johan ${ }^{2}$, RA Kisdjamiatun RMD ${ }^{2}$
}

\begin{abstract}
Background : Diabetes mellitus is a chronic disease caused by acquired deficiency in insulin production by the pancreas, or by the ineffectiveness of using the produced insulin. Oyster mushroom (Pleurotus ostreatus) can help lower blood glucose levels, improve lipid profile and reduce levels of MDA.

Objective : to analyze the effect of oyster mushroom on blood glucose levels, lipid profile and MDA levels in STZ induced rats as type 1 DM model.

Methods : thirty Sprague Dawley rats were randomly divided into 3 groups: one positive group (1) and two treated group which received $100 \mathrm{mg} / \mathrm{kgBB}(2)$ and $200 \mathrm{mg} / \mathrm{kgBB}$ (3) oyster mushroom extract, respectively. The interventions were carried out for 30 days. The examination of blood glucose levels, lipid profile and MDA levels was before and after the intervention. The differences inthe datapre-post interventions were analyzed by paired t-test, whereas the differences between the groups were analyzed by one-way ANOVA and kruskal wallis followed by post hoc analysis.

Results : the treatment group experienced a decrease in blood glucose levels, total cholesterol, LDL cholesterol, triglycerides, MDA and an increase in HDL cholesterol levels post-intervention ( $p<0,001)$. Oyster mushroom extract with the dose of 200 $\mathrm{mg} / \mathrm{kg}$ was more effective in lowering blood glucose levels, MDA levels and improving lipid profiles $(p<0,001)$.

Conclusion : Oyster mushrooms administration lowers blood glucose levels, total cholesterol, LDL cholesterol, triglycerides, MDA and increases HDL cholesterol levels.
\end{abstract}

Keywords : oyster mushroom (Pleurotus ostreatus), blood glucose, lipid profile, Malondialdehyde, diabetes

\begin{abstract}
ABSTRAK
Latar Belakang : Diabetes melitus (DM) merupakan penyakit kronis yang disebabkan karena pankreastidak menghasilkancukup insulin, atau ketika tubuh tidak dapatmenggunakaninsulin secara efektif. Jamur tiram putih (Pleurotus ostreatus) dapat membantu menurunkan kadar glukosa darah, memperbaiki profil lipid dan menurunkan kadar MDA.

Tujuan : menganalisis pengaruh pemberian jamur tiram putihterhadap kadar glukosa darah, profil lipid dan kadar MDA pada tikus yang diinduksi STZ sebagai model DM tipe 1.

Metode : tiga puluh ekor tikus Sprague dawley jantan dibagi dalam 3 kelompok, yaitu satu kelompok positif(1) dan dua kelompok perlakuan yang masing-masing mendapat ekstrak jamur tiram putih $100 \mathrm{mg} / \mathrm{kgBB}$ (2) dan $200 \mathrm{mg} / \mathrm{kgBB}$ (3). Intervensi dilakukan selama 30 hari. Pemeriksaan kadar glukosa darah, profil lipid dan kadar MDA dilakukan sebelum dan sesudah intervensi. Perubahan sebelum-sesudah intervensi dianalisis dengan uji paired t-test, sedangkan perbedaan antara kelompok dianalisis dengan uji one way ANOVA dan Kruskal wallis yang dilanjutkan dengan analisis post hoc.

Hasil : kelompok perlakuan mengalami penurunan kadar glukosa darah, kolesterol total, kolesterol LDL, trigliserida, MDA dan peningkatan kadar kolestrol HDL pasca intervensi ( $<<0,001)$. Ekstrak jamur tiram dosis $200 \mathrm{mg} / \mathrm{kgBB}$ lebih efektif dalam menurunkan kadar glukosa darah, kadar MDA dan memperbaiki profil lipid ( $p<0,001)$.

Kesimpulan :Pemberian jamur tiram putih menurunkan kadar glukosa darah, kolesterol total, kolesterol LDL, trigliserida, MDA dan meningkatkan kadar kolesterol HDL.
\end{abstract}

Kata kunci : jamur tiram putih (Pleurotus ostreatus), glukosa darah, profil lipid, malondialdehyde, diabetes

\section{PENDAHULUAN}

Diabetes melitus (DM) merupakan penyakit degeneratif yang terjadi karena pancreas mengalami kerusakan dalam produksi atau insulin tidak dapat bekerja secara efektif, sehingga hanya sedikit glukosa yang masuk ke sel dan menumpuk dalam darah

\footnotetext{
1. Fakultas Ilmu Kesehatan, Universitas Ngudi Waluyo Semarang (email korespondensi : meika_purbo@yahoo.co.id)

2. Fakultas Kedokteran Universitas Diponegoro Semarang

3. Fakultas Kedokteran Universitas Diponegoro Semarang
}

(hiperglikemia). ${ }^{1,2}$ Ketidaksediaan glukosa dalam sel akan mengakibatkan terjadinya glukoneogenesis secara berlebihan. Lemak dihidrolisis sehingga menghasilkan asam lemak dan gliserol. ${ }^{3}$ Asam lemak yang dihasilkan tidak semuanya mampu dikatabolisme, kelebihannya diesterifikasi menjadi trigliserida dan VLDL.Keadaan hiperglikemia secara sekunder menyebabkan glikosilasi lipoprotein, yang meningkatkan potensial aterogenik dan menuju ke perkembangan penyakit vaskuler. ${ }^{4}$ Keadaan tersebut menyebabkan dislipidemia pada penderita diabetes melitus. ${ }^{5}$ Hiperglikemia pada DM juga menyebabkan 
proses autooksidasi yang memicu pembentukan radikal bebas. Radikal bebas dapat merusak membran sel, menjadi lipid peroksida atau Malondialdehyde (MDA), bila berlanjut mengakibatkan kerusakan sistem membran sel dan kematian sel. ${ }^{6}$

Beberapa studi dengan informasi ilmiah menyatakan bahwa jamur tiram merupakan makanan anti diabetes. Jamur tiram putih telah menunjukkan kecenderungan yang efektif dalam mengontrol glukosa darah. Studi pada tikus DM yang diberikan jamur tiram putih menunjukkan penurunan kadar glukosa darah yang bermakna. ${ }^{7}$ Penelitian sebelumnya juga telah membuktikan pada tikus yang diinduksi Streptozotozin (STZ) menunjukkan bahwa pada kelompok yang diberikan Amaryl dan kelompok yang diberi jamur tiram putih dosis tinggi dan dosis rendah, ketiganya mengalami penurunan glukosa darah secara signifikan setelah 30 hari perlakuan. ${ }^{8}$ Aktivitas antioksidan dari jamur tiram putih dapat menurunkan kadar MDA secara bermakna pada tikus Wistar dengan kerusakan hati. ${ }^{9}$ Kadar MDA belum diamati pada tikus DM yang diberi jamur tiram putih.

Jamur tiram putih merupakan salah satu jamur yang memiliki kandungan beta glucan yang tinggi. ${ }^{10}$ Beta glucan mampu meningkatkan Granulocyte-Colony Stimulating Factor (G-CSF) pada mencit, ${ }^{11}$ dan kemudian meningkatkan pelepasan hematopoetic stem cell dari sumsum tulang ke sirkulasi darah perifier dan bergerak menuju organ yang rusak. ${ }^{12}$ Jamur tiram putih dapat menghambat pembentukan atau biosintesis dari kolesterol, karena mengandung statin (lovastatin). ${ }^{13}$ Lovastatin merupakan senyawa inhibitor kompetitif hidroksi metil glutaril - Coenzim A (HMG-CoA) reduktase yang mampu menurunkan kolesterol plasma. ${ }^{14} \mathrm{Pemberian} 5 \%$ serbuk jamur tiram putih (Pleurotusostreatus) pada tikus hiperkolesterol terbukti mengurangi kolesterol total plasma $28 \%$, kolesterol LDL 55\%, trigliserida $34 \%$, asam lemaknon-esterifikasi sekitar $30 \%$ dan kadar kolesterolhati total $>34 \%$, bersamaan dengan peningkatan konsentrasi kolesterol HDL dalamplasma $>21 \% .^{15}$

Penelitian menggunakan hewan coba untuk studi DM telah banyak dilakukan. Streptozotocin (STZ) sering digunakan sebagai toksin untuk menginduksi hewan coba/tikus menjadi DM. STZ adalah jenis antibiotik spektrum luas dan toksik terhadap sel $\beta$ pankreas yang mempunyai efek terhadap perubahan insulin dan glukosa darah. ${ }^{16}$ Selain itu, hiperlipidemia merupakan komplikasi metabolik secara klinik dan experimental pada diabetes. Peningkatan yang bermakna terjadi pada kadar kolesterol total, trigliserida, kolesterol LDL, dan kolesterol VLDL sedangkan terjadi penurunan kolesterol HDL pada tikus diabetes yang diinduksi STZ. ${ }^{17}$
Penelitian bertujuan untuk mengetahui pengaruhjamur tiram putihterhadap kadar glukosa darah, profil lipid dan kadar MDA pada tikus DM.

\section{BAHAN DAN METODE}

Penelitian ini termasuk eksperimental murni dengan rancangan pre and post test randomized controlled group.Hewan coba yang digunakan adalah rattus norvegicus galur sprague dawleysejumlah 30 ekor yang diinduksi STZ(streptozotocin) $65 \mathrm{mg} / \mathrm{kgBB}$ intraperitonial dan NA (nicotinamide) $230 \mathrm{mg} / \mathrm{kgBB}$ agar menjadi diabetik, sedangkan hewan coba yang sudah dapat dikategorikan diabetik apabila kadar glukosa darah $\geq 200 \mathrm{mg} / \mathrm{dl} .{ }^{7,8}$ Hewan coba yang sudah diabetik, kemudian dibagi dalam 3 kelompok yaitu kelompok kontrol diabetik (tanpa perlakuan), kelompok perlakuan 1 (diberi ekstrak jamur tiram putih $100 \mathrm{mg} / \mathrm{kgBB}$ ) dan kelompok perlakuan 2 (diberi ekstrak jamur tiram putih $200 \mathrm{mg} / \mathrm{kgBB}$ ). Perlakuan diberikan selama 30 hari.

Jamur tiram putih diperoleh dari petani "Jamur Tiram 99" di Desa Nyatnyono Ungaran. Jamur tiram putih segar dicuci dan diiris tipis, kemudian dikeringkan dalam oven pada suhu $40^{\circ} \mathrm{C}$ selama 6 jam. Jamur kering digiling sampai menjadi tepung. Dari 1000 gram jamur tiram segar menjadi 85 gram serbuk jamur tiram putih. Serbuk jamur tiram putih kemudian diekstrak dengan ethanol $80 \%$, residu disaring dan dipekatkan, filtrat yang diperoleh digunakan sebagai ekstrak jamur tiram putih. ${ }^{41}$ Ekstrak jamur tiram putih yang dihasilkan sebanyak 15 gram.

Pengambilan sampel darah melalui pembuluh darah mata (plexus reorbitalis). Darah dipisahkan menjadi serum menggunakan alat sentrifus. Kadar glukosa darah diukur dengan metodeGOD-PAP, kadar kolesterol total, kadar kolesterol LDL dan kadar kolesterol HDL diukur dengan metodeCHOD-PAP, kadar trigliserida dengan GPO, sedangkan kadar MDA plasma dengan metode TBARS.

Penelitian ini dilakukan di Pusat Studi Pangan dan UGM untuk mengekstrak jamur tiram putih dan pemeliharaan hewan coba, perlakuan, analisis kadar glukosa darah, profil lipid dan kadar MDA. Sedangkan pengeringan jamur tiram putih hingga menjadi serbuk dilakukan di Laboratorium Gizi STIKes Ngudi Waluyo Ungaran. Penelitian ini telah mendapatkan persetujuan Komisi Etik Penelitian Kesehatan (KEPK) Fakultas Kedokteran Universitas Diponegoro Semarang dengan nomor 402/EC/FK-RSDK/2014.

Perbedaan kadar glukosa darah, profil lipid dan kadar MDA sebelum dan sesudah perlakuan pada masing-masing kelompok dianalisa dengan uji paired $t$ test. Selanjutnya untuk mengetahui perbedaan antara kelompok digunakan uji one way ANOVA dan Kruskal wallis yang dilanjutkan dengan analisis Post-Hoc. ${ }^{18}$ 


\section{HASIL}

\section{Berat Badan Tikus Selama Per cobaan}

Berat badan tikus pada awal adaptasi tidak terdapat perbedaan antara kelompok percobaan ditunjukkan dengan nilai $\mathrm{p}>0,05$ dengan uji beda one way ANOVA. Hal tersebut membuktikan bahwa di antara kelompok percobaan memiliki variasi atau karakteristik yang homogen. Tikus pada setiap kelompok mengalami penurunan berat badan secara bermakna setelah 5 hari pasca diinduksi STZ.
Perbedaan rerata berat badan terjadi saat akhir perlakuan dengan hasil uji one way ANOVA nilai $\mathrm{p}<$ 0,001 . Hasil analisis uji paired t-test menunjukkan bahwa tikus pada kelompok kontrol diabetik mengalami penurunan berat badan sejak diinduksi STZ dan terus mengalami penurunan selama 30 hari penelitian $(p<0,05)$. Sedangkan pada kelompok tikus yang diberi ekstrak jamur tiram putih $100 \mathrm{mg} / \mathrm{kgBB}$ dan $200 \mathrm{mg} / \mathrm{kgBB}$ mengalami kenaikan berat badan yang bermakna $(p<0,05)$. Kenaikan berat badan lebih tinggi pada kelompok tikus yang diberi ekstrak jamur tiram $200 \mathrm{mg} / \mathrm{kgBB}$ yaitu sebesar 36,10 $\pm 0,32$ gram.

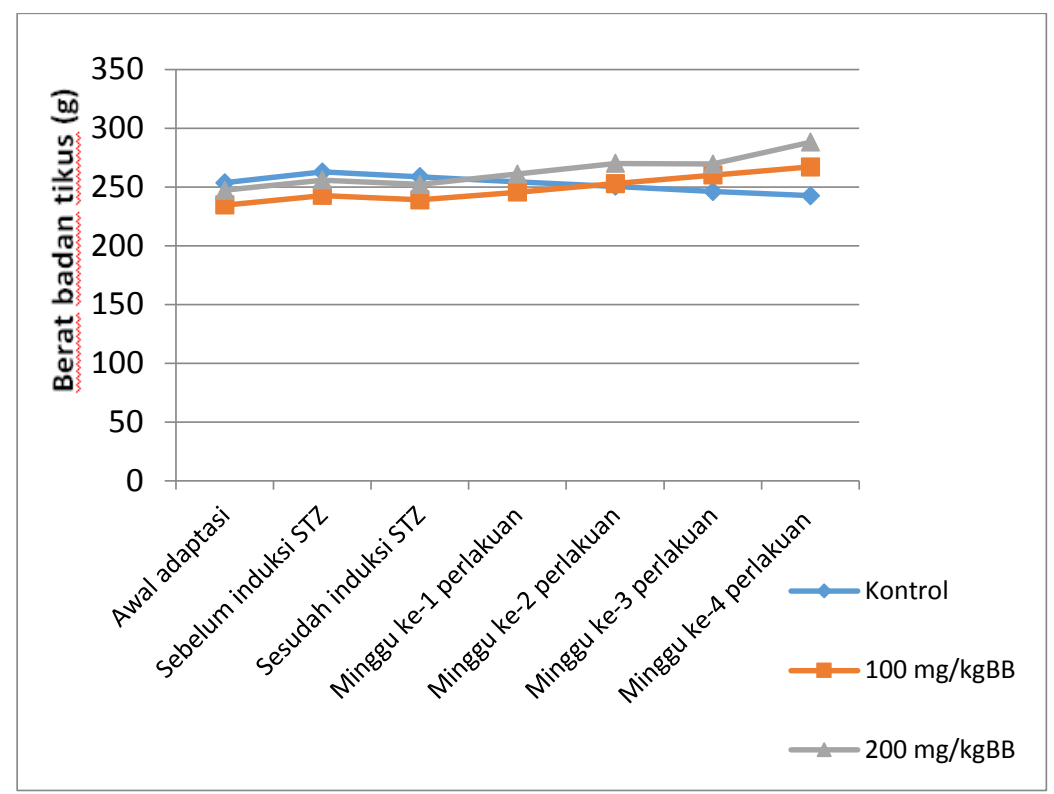

\section{Gambar 1. Diagram perubahan berat badan tikus selama percobaan}

\section{Kadar Glukosa Darah}

Tikus mengalami kenaikan kadar glukosa darah (> $200 \mathrm{mg} / \mathrm{dl})$ setelah 5 hari pasca induksi STZ. Hasil analisa uji one way ANOVA menunjukkan bahwa tidak ada perbedaan kadar glukosa darah antara kelompok tikus coba sebelum diinduksi STZ, begitu juga kadar glukosa darah antara kelompok tikus coba sesudah diinduksi STZ $(\mathrm{p}>0,05)$. Perbedaan rerata kadar glukosa darah secara bermakna terjadi pada akhir perlakuan, ditunjukan dengan nilai $p<0,001$, kemudian dilanjutkan dengan analisa post-hoc yang menunjukkan terdapat perbedaan rerata kadar glukosa darah antara masing-masing kelompok. Penurunan lebih besar terdapat pada kelompok pemberian dosis $200 \mathrm{mg} / \mathrm{kgBB}$ dengan penurunan kadar glukosa darah sebesar $135,2 \pm 1,07 \mathrm{mg} / \mathrm{dl}$.

Hasil uji Paired t-test pada kelompok kontrol diabetik menunjukkan peningkatan kadar glukosa yang bermakna $(\mathrm{p}<0,001)$, sedangkan pada kelompok perlakuan keduanya mengalami penurunan kadar glukosa darah secara bermakna $(\mathrm{p}<0,001)$ selama intervensi.

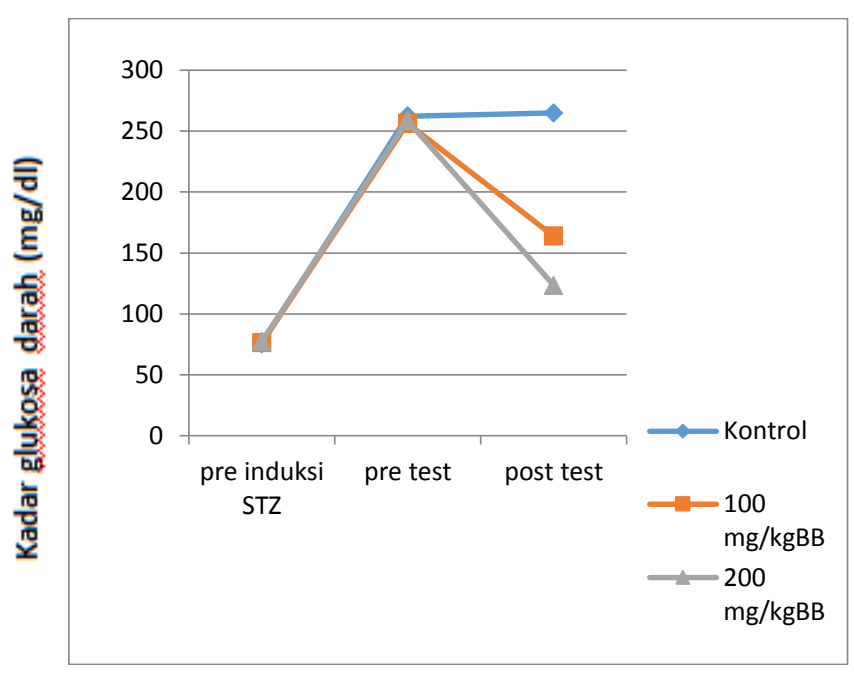

Gambar 2. Diagram perubahan kadar glukosa darah tikus selama percobaan

\section{Profil Lipid}

Hasil analisa uji beda one way ANOVA dan uji kruskal wallis yang dilanjutkan dengan analisa posthocmenunjukkan adanya perbedaan kadar kolesterol 
total, kolesterol LDL, kolesterol HDL dan trigliserida yang bermakna antar kelompok setelah masa perlakuan jamur tiram putih. Perubahan yang paling besar yaitu kelompok perlakuan dengan dosis ekstrak jamur tiram putih $200 \mathrm{mg} / \mathrm{kgBB}$, sehingga dapat disimpulkan bahwa dosis ekstrak jamur tiram putih $200 \mathrm{mg} / \mathrm{kgBB}$ lebih efektif menurunkan kadar kolesterol total, kolesterol LDL, trigliserida dan meningkatkan kolesterol HDL daripada dosis $100 \mathrm{mg} / \mathrm{kgBB}$.

Tabel 1. Profil lipid tikus coba selama penelitian

\begin{tabular}{|c|c|c|c|c|c|}
\hline & & & Kelompok & & \\
\hline & fil Lipid & Kontrol Diabetik & $\begin{array}{c}\text { Dosis 100 } \\
\text { mg/kgBB* }\end{array}$ & $\begin{array}{l}\text { Dosis 200 } \\
\text { mg/kgBB* }\end{array}$ & $\mathbf{p}$ \\
\hline Kadar & Sebelum perlakuan & $163,74 \pm 4,69$ & $165,92 \pm 5,41$ & $164,98 \pm 4,78$ & $0,622^{(a)}$ \\
\hline kolesterol & Sesudah perlakuan & $172,82 \pm 5,92$ & $140,15 \pm 7,02$ & $97,99 \pm 6,86$ & $0,001^{\text {(a) }}$ \\
\hline total & $\Delta$ & $9,08 \pm 3,90$ & $-25,76 \pm 9,71$ & $-66,99 \pm 7,20$ & $0,000^{(b)}$ \\
\hline & $\mathrm{P}$ & $0,000^{(\mathrm{c})}$ & $0,000^{(\mathrm{c})}$ & $0,000^{(\mathrm{c})}$ & \\
\hline Kadar & Sebelum perlakuan & $62,23 \pm 3,44$ & $57,52 \pm 2,94$ & $57,96 \pm 1,63$ & $0,001^{(a)}$ \\
\hline kolesterol & Sesudah perlakuan & $67,09 \pm 3,96$ & $33,48 \pm 5,43$ & $16,99 \pm 4,46$ & $0,000^{(\mathrm{a})}$ \\
\hline LDL & $\Delta$ & $4,86 \pm 1,75$ & $-24.04 \pm 6,29$ & $-40,97 \pm 5,64$ & $0,000^{(b)}$ \\
\hline & $\mathrm{P}$ & $0,000^{\text {(c) }}$ & $0,000^{(\mathrm{c})}$ & $0,000^{(\mathrm{c})}$ & \\
\hline Kadar & Sebelum perlakuan & $23,77 \pm 2,75$ & $19,28 \pm 1,91$ & $20,65 \pm 3,04$ & $0,002^{\text {(a) }}$ \\
\hline kolesterol & Sesudah perlakuan & $23,00 \pm 2,56$ & $37,81 \pm 6,03$ & $54,09 \pm 5,82$ & $0,000^{(\mathrm{b})}$ \\
\hline HDL & $\Delta$ & $-0,77 \pm 1,14$ & $18,54 \pm 6,38$ & $33,43 \pm 5,77$ & $0,000^{(\mathrm{b})}$ \\
\hline & $\mathrm{P}$ & $0,060^{(\mathrm{c})}$ & $0,000^{(c)}$ & $0,000^{(\mathrm{c})}$ & \\
\hline Kadar & Sebelum perlakuan & $84,70 \pm 2,23$ & $89,18 \pm 4,76$ & $87,09 \pm 1,83$ & $0,054^{(b)}$ \\
\hline trigliserida & Sesudah perlakuan & $85,63 \pm 2,11$ & $59,63 \pm 6,65$ & $30,48 \pm 5,85$ & $0,000^{(b)}$ \\
\hline & $\Delta$ & $0,93 \pm 2,61$ & $-29,55 \pm 9,94$ & $-56,60 \pm 6,93$ & $0,000^{(b)}$ \\
\hline & $\mathrm{P}$ & $0,289^{\text {(c) }}$ & $0,000^{(\mathrm{c})}$ & $0,000^{(\mathrm{c})}$ & \\
\hline
\end{tabular}

a) Uji One way ANOVA ( $\mathrm{p}<0,05$ ), untuk menganalisa perbedaan antar kelompok percobaan

b) Kruskal wallis test ( $\mathrm{p}<0,05)$, untuk menganalisa perbedaan antar kelompok percobaan

c) Uji Paired t-test ( $\mathrm{p}<0,05)$, untuk menganalisa perbedaaan sebelum dan sesudah perlakuan

*) Perlakuan (pemberian ekstrak jamur tiram putih) dilakukan pada tikus sesudah diinduksi STZ

\section{Kadar MDA}

Dalam penelitian ini, hasil uji Paired t-test menunjukkan bahwa kelompok kontrol mengalami peningkatan kadar MDA yang bermakna $(\mathrm{p}<0,05)$, sedangkan pada kelompok perlakuan keduanya mengalami penurunan kadar MDA secara bermakna $(\mathrm{p}<0,05)$ sebelum dan sesudah perlakuan. Analisa one way ANOVA juga menunjukkan adanya perbedaan yang bermakna antara kelompok pada akhir perlakuan $(\mathrm{p}<0,05)$, dimana penurunan kadar MDA lebih besar terdapat pada kelompok pemberian dosis $200 \mathrm{mg} / \mathrm{kgBB}$ dengan penurunan kadar MDA sebesar 6,19 $\pm 0,38$ $\mathrm{mg} / \mathrm{dl}$.

Tabel 2. Kadar MDA tikus coba selama penelitian

\begin{tabular}{|c|c|c|c|c|}
\hline \multirow[b]{2}{*}{ Kadar MDA } & \multicolumn{3}{|c|}{ Kelompok } & \multirow[b]{2}{*}{$\mathbf{P}$} \\
\hline & Kontrol Diabetik & $\begin{array}{c}\text { Dosis } 100 \\
\text { mg/kgBB* }\end{array}$ & $\begin{array}{l}\text { Dosis 200 } \\
\text { mg/kgBB* }\end{array}$ & \\
\hline $\begin{array}{l}\text { Sebelum } \\
\text { perlakuan (pre } \\
\text { test) }\end{array}$ & $7,70 \pm 0,09$ & $7,94 \pm 0,10$ & $8,25 \pm 0,34$ & $0,003^{(\mathrm{a})}$ \\
\hline $\begin{array}{l}\text { Sesudah } \\
\text { perlakuan (post } \\
\text { test) }\end{array}$ & $7,77 \pm 0,32$ & $5,32 \pm 0,35$ & $2,06 \pm 0,40$ & $0,000^{(\mathrm{a})}$ \\
\hline$\Delta$ pre-post test & $0,07 \pm 0,06$ & $-2,62 \pm 0,33$ & $-6,19 \pm 0,38$ & $0,000^{(\mathrm{b})}$ \\
\hline $\mathrm{P}$ & $0,007^{(\mathrm{c})}$ & $0,000^{(\mathrm{c})}$ & $0,000^{(\mathrm{c})}$ & \\
\hline $\begin{array}{l}\text { a) Uji One way A } \\
\text { b) Kruskal wallis } \\
\text { c) Uji Paired t-te } \\
\text { *) Perlakuan (pem }\end{array}$ & an ekstrak jamur tiram & dilakukan pad & sesudah diinduk & \\
\hline
\end{tabular}




\section{PEMBAHASAN}

Tikus mengalami penurunan berat badan secara bermakna setelah 5 hari pasca diinduksi STZ. Penurunan berat badan pada tikus diabetes melitus disebabkan karena tikus pada kondisi diabetes melitus tidak mampu menggunakan glukosa sebagai sumber energi. Kekurangan insulin menyebabkan glukosa tidak bisa masuk ke dalam sel sehingga kebutuhan energi untuk tubuh diperoleh dari hasil lipolisis. Lemak diberbagai jaringan dimobilisasi dan didegradasi melalui proses beta oksidasi untuk menghasilkan energi. Kehilangan lemak menyebabkan berat badan menurun. Hal yang sama juga dilaporkan oleh Wang et al. (2012), bahwa terjadi penurunan berat badan pada tikus sprague dawley setelah 8 hari diinduksi STZ. ${ }^{19}$

Peningkatan berat badan pada kelompok yang diberikan ekstrak jamur tiram putih karena beta glukan mampu mengaktifkan sel beta pankreas untuk produksi insulin, sehingga insulin menjadi normal dan sel mendapat cukup energi. Hal ini menyebabkan glukosa dapat disimpan dengan baik dalam otot dan hati sehingga bobot badan tikus berangsur - angsur menjadi meningkat. ${ }^{20}$

Beta (1,3/1,6)-D-glucan, isolasi polisakarida insoluble dari jamur Pleurotus ostreatus, merupakan suplemen gizi yang memiliki efek sebagai imunomodulator non spesifik dengan aktivitas antioksidan. ${ }^{21}$ Studi pada mencit menunjukkan bahwa beta glucan spesifik dari jamur seperti Pleurotus ostreatus, Sclerotinia sclerotiorum dan Sparassis crispa, dapat meningkatkan hematopoiesis dan melindungi sel sumsum tulang, sehingga HSC dilepaskan ke darah perifer. ${ }^{22,23}$

Hematopoietic stem cell (HSC)adalah sel induk dewasa yang memiliki potensi untuk memperbaharui diri dan berdiferensiasi menjadi sel darah yang berfungsi dalam beberapa aktivitas biologis: keseimbangan homeostasis, fungsi kekebalan tubuh, dan respon terhadap mikroorganisme dan inflamasi.Selain itu HSC diketahui dapat berdiferensiasi menjadi sel khusus (sifat plastisitas) seperti adipocytes, kardiomiosit, sel-sel endotel, fibroblas/myofibroblasts, sel-sel hati, osteochondrocytes, dan sel pankreas. ${ }^{23}$

Sel beta pankreas mensekresi hormon insulin dalam jumlah yang cukup sesuai jumlah glukosa dalam darah. Insulin akan merangsang pengambilan glukosa oleh jaringan dan kemudian memecahnya menjadi energi, menyimpannya dalam bentuk glikogen dan mengubahnya menjadi lemak. Dengan proses tersebut diatas, kadar gula darah akan menurun dan kembali menuju normal. ${ }^{24}$

Insulin menghambat sintesis trigliserida dan menurunkan produksi VLDL oleh hati. VLDL mengalami hidrolisis lebih lanjut menjadi IDL yang mengandung kolesterol dan trigliserida dalam jumlah yang sama. Hati menghilangkan kira-kira 40-60\% VLDL remnant dan IDL lewat endositosis yang diperantarai oleh reseptor LDL dengan mengikat apo E. Sisa IDL dimodifikasi oleh lipase hepatik untuk membentuk LDL. Kira-kira 70\% LDL yang ada dalam sirkulasi dibersihkan lewat endositosis melalui reseptor LDL dalam hati. ${ }^{5}$ Jumlah kolesterol yang akan teroksidasi tergantung dari kadar kolesterol yang terkandung di LDL. Beberapa sediaan mempengaruhi tingkat oksida seperti: meningkatnya jumlah LDL kecil padat (small dense $L D L$ ) seperti pada sindrom metabolik dan diabetes melitus dan meningkatnya kadar kolesterol HDL, makin tinggi kadar kolesterol HDL akan bersifat protektif terhadap oksidasi LDL. ${ }^{26}$

Jamur tiram putih juga bersifat hipokolesterolemik karena mengandung lovastatin tinggi yang menghambat aktivitas enzim 3-hidroksi-3metilglutarl koenzimA(HMG-CoA) reduktase, sehingga membatasi sintesis kolesterol. ${ }^{27}$ Lovastatin bekerja dengan cara menghambat kerja enzim HMGKoA reduktase. Jika lovastatin mempunyai konsentrasi lebih besar dari HMG-KoA, maka HMG-KoA akan berikatan dengan lovastatin. ${ }^{28}$ Hal ini akan menyebabkan sintesis kolesterol terhambat. Kolesterol yang terhambat akan menghambat sintesis VLDL dalam hati. Penghambatan sintesis VLDL secara otomatis akan menekan jumlah LDL dalam darah dan LDL yang ditangkap reseptor LDL diubah menjadi HDL sehingga akan meningkat jumlahnya. ${ }^{25,29}$

Pemberian jamur tiram putih dapat menurunkan kadar MDA pada tikus diabetes. Jumlah insulin yang cukup dapat menekan reaksi glikasi (reaksi non enzimatik antara glukosa dengan protein) dan menurunkan pembentukan radikal bebas, sehingga pembentukan peroksidasi lipid dan kadar MDA menurun. ${ }^{30}$ Beta glucan yang terkandung pada jamur tiram putih juga bersifat sebagai antioksidan yang menghambat peroksidasi lipid dan mengatur jumlah status oksidan dan antioksidan pada tikus diabetes. Selain itu, polisakarida berperan penting sebagai penangkal radikal bebas dan melindungi jaringan terhadap kerusakan oksidatif. ${ }^{31}$

\section{SIMPULAN}

1. Penurunan kadar glukosa darah, kadar kolesterol total, kadar kolesterol LDL, kadar trigliserida dan kadar MDA terbukti pada kelompok tikus DM yang telah diberikanjamur tiram putih.

2. Peningkatan kadar kolesterol HDL terbukti pada kelompok tikus DM yang telah diberikan jamur tiram putih.

3. Pemberian ekstrak jamur tiram putih dosis 200 $\mathrm{mg} / \mathrm{kgBB}$ lebih efektif menurunkan kadar glukosa darah, kadar kolesterol total, kadar kolesterol LDL, 
kadar trigliseridadan kadar MDA serta meningkatkan kadar kolesterol HDL pada tikus DM dibandingkan dengan dosis $100 \mathrm{mg} / \mathrm{kgBB}$.

\section{SARAN}

Perlu penelitian lebih lanjut dengan dilakukan pemeriksaan kadar insulin dan patologi anatomi pankreas, serta dilakukan analisa kadar beta glucan dan lovastatin pada jamur tiram putih, khususnya "Jamur tiram putih 99" dari Desa Nyatnyono Ungaran.

\section{DAFTAR PUSTAKA}

1. WHO. Diabetes. Online Available at http://who.int/topics/diabetes_mellitus/en/ 15 Juni 2013.

2. Maulana M. Diabetes Melitus Jogjakarta: Katahati; 2008.

3. King M W. Glycolysis: Process of Glucose Utilization and Homeostasis; 2007.

4. Luman A. Diabetes dan Penyakit Kardivaskuler. Divisi Kardiologi Departemen Ilmu Penyakit Dalam USU; 2012.

5. Fauci AS, Kasper DL, Braunwald E, Hauser SL, Longo DL, Jameson JL, et al. Harrison's principles of internal medicine (17th ed.). New York: McGraw-Hill Medical Publishing Division; 2008: 2286 - 94.

6. Yasa IWPS, Suastika K, Djelantik AAGS, Astawa INM. Hubungan Positif antara Ulkus Kaki Diabetik dengan Presentase Sel Bermarkah CD4+ Pembawa Malondialdehid. 2007. Online Available at

http://ejournal.unud.ac.id/abstrak/sutirta_yasa_pdf .pdf 19 Februari 2014.

7. Al-Malki A. 2012. Effect of Pleurotus ostreatus on hyperglycemia, DNA damage and chromosomes aberrations. Biomedical Science and Engineering 2012; 5:657-63.

8. Ghaly IS, Ahmed ES, Booles HF, Farag IM, Nada SA. Evaluation of Antihyperglycemic Action of Oyster Mushroom (Pleurotus ostreatus) and Its Effect on DNA Damage, Chromosome Aberrations and Sperm Abnormalities in StreptozotocinInduced Diabetic Rats. Global Veterinaria 2011;7(6):532-44.

9. Jayakumar T, Ramesh E, Geraldine P. Antioxidant activity of the oyster mushroom, Pleurotus ostreatus, on CCl4-induced liver injury in rats. Food and Chemical Toxicology 2006;44:1989-96.

10. Bobek dan Galbavy. Effect of pleuran (beta-glucan from Pleurotus ostreatus) on the antioxidant status of the organism and on dimethylhydrazine-induced precancerous lesions in rat colon. British Journal of Biomedical Science 2001;58(3):164-8.
11. Lin H, de Stanchina E, Zhou XK, Hong F, Seidman A, Fornier M, et al. Maitake beta-glucan promotes recovery of leukocytes and myeloid cell function in peripheral blood from paclitaxel hematotoxicity. Cancer Immunology, Immunotherapy 2009;59(6):885-97.

12. Goodman JW, Hodgson GS. 1990. Evidence for stem cells in the peripheral blood of mice. Blood 19:702-14.

13. Alarcón J, Aguila S, Arancibia-Avila P, Fuentes O, Zamorano-Ponce E, Hernández M.Production and Purification of Statins from Pleurotus ostreatus (Basidiomycetes) Strains. Zeitschrift fur Naturforsch C, Journal of Biosciences 2003;58c:62-4

14. Goodman and Gilman. Dasar Farmakologi Terapi Volume 2. Jakarta: Penerbit Buku Kedokteran EGC;2001.

15. Hossain $\mathrm{S}$, Hashimoto M, Choudhury EK, Alam N, Hussain S, Hasan $\mathrm{M}$, et al. Dietary mushroom (Pleurotus ostreatus) ameliorates atherogenic lipid in hypercholesterolemic rats. Clinical and Experimental Pharmacology \& Physiology 2003;July30(7):470-5. (PubMed).

16. Abeeleh MA, Ismail ZB, Alzaben KR, AbuHalaweh SA, Al-Essa MK, Abuabeeleh J, et al. Induction of Diabetes Mellitus in Rats Using Intraperitoneal Streptozotocin: A Comparison between 2 Strain of Rats. European Journal of Scientific Research 2009;32(3):398-402.

17. Komolafe O, Adeyemi D, Adewole S, Obuotor E. Streptozotocin-Induced Diabetes Alters The Serum Lipid Profiles Of Adult Wistar Rats. The Internet Journal of Cardiovascular Research 2008;7(1).

18. Dahlan MS. Statistik untuk Kedokteran dan Kesehatan Edisi 5. Jakarta: Salemba Medika; 2011: 87-113.

19. Wang HQ, Zou JJ, Zhou XH, Ji LN, Liu ZM. Effects of Chinese medicine Tongxinluo on hyperglycemia and beta-cell damage in streptozotocin-induced diabetic rats. Chinese Medical Journal 2012. 125(20):3675-80.

20. Puspati Ni KS, Anthara MS, Dharmayudha AAG. Pertambahan Bobot Badan Tikus Diabetes Mellitus dengan Pemberian Ekstrak Etanol Buah Naga Daging Putih. Indonesia Medicus Veterinus 2013; 2(2): $225-34$.

21. Nosalova V, Bobek P, Cerna S, Galbavy S, Stvrtina S.Effects of pleuran (beta-glucan isolated from Pleurotus ostreatus) on experimental colitis in rats. Physiological Research/Academia Scientiarum Bohemoslovaca 2001;50(6):575-81.

22. Kodama N, Komuta K, Nanba H: Can maitake MD-fraction aid cancer patients? Alternative Medicine Review: a journal of clinical therapeutic 2002;7(3):236-9. 
23. Chotinantakul K, Leeanansaksiri W. Review Article: Hematopoietic Stem Cell Development, Niches, and Signaling Pathways. Bone Marrow Research 2012; 2012: 270425.

24. Hutagalung, H. Karbohidrat 2004. Diakses dari http://repository.usu.ac.id/bitstream/123456789/3 561/1/gizi-halomoan.pdf tanggal 21 September 2012.

25. Murray RK, Granner DK, Mayes PA, Rodwell VW. Biokimia Harper Edisi 25. Jakarta: Penerbit Buku Kedokteran EGC; 2003.

26. Sudoyo AW, Setiyohadi B, Alwi I, Simadibrata M, Setiati S. Buku Ajar Ilmu Penyakit Dalam. Jakarta: Interna Publishing; 2009: 1880-984.

27. Alam N, Yoon KN, Lee TS, Lee UY. Hypolipidemic Activities of Dietary Pleurotus ostreatusin Hypercholesterolemic Rats. The Korean Society of Mycology 2011; 39(1): 45-51.

28. Mahan LK, Stump SE,Krause's Food andNutritionTherapy 12thedition.Canada: Saunders Elsevier; 2008: 833-6.

29. Guytan AC, Hall EJ. Metabolisme Lipid (Buku Ajar Fisiologi KedokteranEdisi 11). Jakarta: Penerbit Buku Kedokteran EGC; 2007: 883-94.

30. Abdelazim AM, Afifi M. Oyster mushroom (Pleurotus ostreatus) strain 238 ameliorates the oxidative stress in STZ-induced diabeticmice. Life Science Journal 2013;10(3).

31. Kofuji K, Aoki A, Murata Y. Antioxidant Activity of $\beta$-Glucan. Pharmaceutics2012; 2012: 125864. 